\title{
Thermal performance of the European flat oyster, Ostrea edulis (Linnaeus, 1758)—explaining ecological findings under climate change
}

\author{
Charlotte Eymann ${ }^{1}$. Sandra Götze ${ }^{1}$. Christian Bock ${ }^{1}$. Helga Guderley ${ }^{2}$ - Andrew H. Knoll ${ }^{3}$. Gisela Lannig ${ }^{1}$. \\ Inna M. Sokolova ${ }^{4} \cdot$ Martin Aberhan $^{5} \cdot$ Hans-O. Pörtner $^{1}$ (1)
}

Received: 20 April 2019 / Accepted: 6 November 2019

(c) Springer-Verlag GmbH Germany, part of Springer Nature 2020

\begin{abstract}
Climate change challenges marine organisms by constraining their temperature-dependent scope for performance, fitness, and survival. According to the concept of Oxygen and Capacity Limited Thermal Tolerance (OCLTT), the overall thermal performance curve relates to an organism's aerobic power budget, its overall aerobic scope for growth, exercise, reproduction, and other performances. We hypothesize that physiological principles shaping tolerance in extant ecosystems have also been operative during climatic changes in the distant past. To compare response patterns in extant fauna and their palaeo-relatives, we started here by studying the metabolic background of performance in the European flat oyster Ostrea edulis at organismic and cellular levels, focusing on the acute thermal window and the metabolic changes towards upper lethal temperatures. We investigated the response of the oysters (pre-acclimated at $12{ }^{\circ} \mathrm{C}$ ) to a short-term warming protocol (by $2{ }^{\circ} \mathrm{C}$ every $48 \mathrm{~h}$ ) from 14 to $36{ }^{\circ} \mathrm{C}$ which we identified as the lethal temperature. At the organismic level, heart and filtration rates were recorded. Gill metabolites were studied by ${ }^{1} \mathrm{H}$ NMR spectroscopy to address thermal responses at the cellular level. Feeding activity by $O$. edulis (assessed by the filtration rates) was highest between 18 and $24{ }^{\circ} \mathrm{C}$ when overall energy expenditure (indicated by heart rate as a proxy for routine metabolic rate) was moderate. We conclude that this range reflects the thermal optimum of this species. Beyond $26{ }^{\circ} \mathrm{C}$, the gill tissue of $O$. edulis became partly anaerobic, and cardiac dysfunction (arrhythmia) developed at $28{ }^{\circ} \mathrm{C}$ followed by an Arrhenius break point $\left(30{ }^{\circ} \mathrm{C}\right)$. This mirrors performance constraints and indicates a wide temperature range of passive tolerance which may be a long-standing characteristic of ostreids supporting survival in extreme environments as well as during past and present climate oscillations.
\end{abstract}

Charlotte Eymann and Sandra Götze were the lead authors contributing equally to this paper.

Responsible Editor: A. E. Todgham.

Reviewed by undisclosed experts.

Hans-O. Pörtner

Hans.Poertner@awi.de

1 Alfred Wegener Institute Helmholtz Centre for Polar and Marine Research, Am Handelshafen 12, 27515 Bremerhaven, Germany

2 Department of Biology, Institut de Biologie Integrative et des Systemes, 1030 Avenue de la Medecine Universite Laval, Quebec, QC G1V 0A6, Canada

\section{Introduction}

Marine ecosystems are currently challenged by increasing atmospheric $\mathrm{CO}_{2}$ concentrations and associated climate change, which cause ocean warming, acidification, and progressive hypoxia, the latter as a result of reduced oxygen solubility and increased water column stratification (Sabine et al. 2004; Hoegh-Guldberg and Bruno 2010; Pörtner 2014). Temperature is a key driver of ongoing global change.

3 Department of Organismic and Evolutionary Biology, Harvard University, Cambridge, MA 02138, USA

4 Marine Biology, Faculty of Mathematics and Natural Sciences, University of Rostock, Rostock, Germany

5 Museum für Naturkunde, Leibniz Institute for Evolution and Biodiversity Science, 10115 Berlin, Germany 
Under unabated warming, the global mean ocean surface temperature is expected to increase by $1.8-4{ }^{\circ} \mathrm{C}$ by the end of the twenty-first century (Rhein et al. 2013). This will drive shifts in the geographical and depth distribution of species (Beukema et al. 2009; Calosi et al. 2016; Koenigstein et al. 2016), leading to shifts in the composition of marine communities, reduced complexity of benthic habitat and loss of some species (e.g., Garrabeu et al. 2009; Bertolino et al. 2015; Cattaneo-Vietti 2018). The impact of warming on marine organisms is likely to depend on their fundamental thermal niche relative to the realized niche occupied in their current habitats, so that species living near their thermal tolerance limits will be harmed by warming, while those living at temperatures below their thermal optimum may benefit from warming, e.g., through increased growth, reproduction, or recruitment (Shepard et al. 2010).

The changes in the ocean projected for this century and beyond may reach extreme values depending on emissions scenarios and extreme events such as marine heat waves. Similar to projections of ecosystem changes caused by ongoing climate change, past ocean changes of the three drivers of marine global change even larger than those anticipated for the twenty-first century, caused ecological crises characterized by species losses and distributional changes (Bambach et al. 2004; Knoll et al. 2007; Joachimski et al. 2012). During the end-Permian mass extinction 252 million years ago, over $80 \%$ of the marine fauna went extinct, as sea surface temperatures increased by up to $11^{\circ} \mathrm{C}$ (Wignall and Twitchett 1996; Stanley 2016; Penn et al. 2018). Experimental studies of extant fauna simulating different climate futures support a basic understanding of how climate change will impact marine fauna and how it may have done so in the distant past, assuming similar physiological mechanisms in place. As the capacities of individual species and functional groups to cope with environmental changes may differ, comparative studies of extant relatives of species and groups may provide explanations of ongoing ecological change as well as patterns of extinction as observed in the palaeo-record of past evolutionary crises.

Temperature is an abiotic factor with a pervasive effect on all levels of an animal's physiology and aerobic performance (Hochachka and Somero 2002; Pörtner 2014). The relationship between temperature and organism performance has been described by the oxygen- and capacity-limited thermal tolerance (OCLTT) concept established by Pörtner (2001) and Pörtner et al. (2009, 2017). According to OCLTT, the range of active thermal tolerance is the thermal range of survival at individual to population levels, since maintenance costs and additional functions, such as growth, reproduction, and species interactions are fully covered by aerobic metabolism. The more temperature exceeds the optimum range, the more aerobic power budget decreases beyond pejus limits (conditions are getting worse) due to an over-proportional rise in energetic costs which demand an increasing fraction of oxygen supply, finally resulting in the onset of anaerobiosis (beyond a critical temperature), and ultimately, death of the organism. Accordingly, the OCLTT concept helps to understand physiological capacities of a species in relation to their environmental niches (Pörtner et al. 2017). Key parameters required to understand the effects of temperature on aerobic power scope include measures of energy demand [such as the oxygen uptake rate $\left(\mathrm{MO}_{2}\right)$ ], as well as the traits related to oxygen uptake and distribution (including ventilation rates, cardiac function, and blood oxygen content), ideally combined with whole animal performance indicators such as growth, activity, or reproduction. Further drivers such as ocean acidification or hypoxia may influence these basic responses to temperature as well as the respective OCLTT indicators.

Previous studies have shown a strong positive correlation between $\mathrm{MO}_{2}$ and heart rate in marine invertebrates (HR, Marshall and McQuaid 1992; Schiffer et al. 2014; Bakhmet 2017), and HR measurements have been used to determine thermal tolerance windows in mollusks (Zittier et al. 2015; Xing et al. 2016). Heart rate (HR) was shown to increase exponentially with increasing temperature until reaching a species-specific break point beyond which HR dropped in mollusks and crustaceans (Widdows 1973; Frederich and Pörtner 2000; Braby and Somero 2006; Xing et al. 2016). The cardiograms of stressed molluscs also displayed arrhythmic and asystolic heart beats (Nicholson 2002; Domnik et al. 2016).

Filtration rate is another important performance indicator in bivalves. Temperature-dependent filtration rate is a major contributor to the aerobic power budget of bivalve mollusks, because filtration is essential for both oxygen uptake at the gills and nutrient delivery. In bivalves, filtration rates are strongly affected by temperature (Møhlenberg and Riisgård 1978; Jørgensen et al. 1990), reflecting altered water viscosity (Petersen et al. 2003) and metabolic capacity (Specht and Fuchs 2018), with consequences for an organism's energy budget. Therefore, the temperature window, where cardiac function and filtration rates can be optimally or at least adequately maintained is linked with the thermal tolerance limit, where long-term energy homeostasis and positive aerobic power scope can be sustained. While the overall metabolic balance involving optimal cardiac performance and oxygen and food uptake (e.g., through filtration) ensures long-term survival and fitness of an organism, the ability to withstand extreme warming (such as can occur during prolonged heat waves) is important in determining the thermal tolerance limits.

During warming, the transition to partial anaerobiosis occurs well before the lethal temperature is reached. In parallel, metabolic depression may reduce energy demand extending survival. Transition to partial anaerobiosis might 
be related to a critical decrease in the oxygen content of the mantle cavity as also seen in the body fluids of other invertebrates (Taylor 1976; Brinkhoff et al. 1983; review by De Zwaan and Wijsmann 1976), reflecting a mismatch between oxygen supply and demand (e.g., Frederich and Pörtner 2000; Melzner et al. 2007; Giomi and Pörtner 2013).

As part of a larger effort to systematically compare the vulnerability of various bivalve groups to climate change (ongoing and during the geological past, DFG-funded Research Group Tersane), we study the development of thermal constraints in the European flat oyster Ostrea edulis (O. edulis, Linnaeus, 1758), a molluscan keystone species that occurs naturally in the North-Eastern Atlantic, from the Norwegian coast down to Morocco, and in the entire Mediterranean Basin (FAO). When measuring survival, filtration rate, heart rate, and cellular biomarkers for anaerobiosis, we follow the hypothesis that physiological principles identified in extant fauna have also shaped the survival, performance, geographical distribution, and demise of related marine fauna in the distant past (Pörtner et al. 2005; Knoll et al. 2007). Responses to climate-induced changes in ambient drivers such as temperature, $\mathrm{CO}_{2}$ and oxygen (Penn et al. 2018) can in fact constrain geographical distribution. However, associated extinction risks are not sufficiently considered (Finnegan et al. 2015). As a first step, we aim to link the observed temperature-induced changes at different functional levels and define the oyster's fundamental thermal niche for later comparison to other bivalve species and groups in extant fauna and palaeo-analogues. We chose oysters as a model organism, because fossils suggest that this clade shows relatively high tolerance to environmental perturbation as well as strong competitiveness against other molluscan species (Guo et al. 2018).

\section{Materials and methods}

\section{Animal origin and maintenance}

Adult, raft cultured Ostrea edulis grown in the estuary of Vigo (Spain, CF-139: Ría de Ferrol $43^{\circ} 27.86$ N, $8^{\circ} 11.84 \mathrm{~W}$; $C F-168$; Ria de Ares $43^{\circ} 24.82, \mathrm{~N}^{\circ} 09.70 \mathrm{~W}$; and $C F-095$ Ria de Ares $43^{\circ} 24.55, \mathrm{~N} 8^{\circ} 10.16 \mathrm{~W}$ ) and exposed to the full range of natural environmental conditions, were obtained from the Biological Station of Toralla (ECIMAT, University of Vigo) in spring 2017. Environmental conditions at the time of collection were as follows: water temperature $\sim 14{ }^{\circ} \mathrm{C}$ and a salinity of $\sim 33$ PSU. Oysters had an average size of $6.7 \pm 0.5 \mathrm{~cm}$ in length, and $6.5 \pm 0.7 \mathrm{~cm}$ in width. The mean total weight was $63 \pm 12 \mathrm{~g}$. Oysters were wrapped in wet tissues and transported to the Alfred-Wegener Institute Helmholtz Center for Polar and Marine Research (AWI, Bremerhaven) by the air within $24 \mathrm{~h}$ after collection. Upon arrival, the animals were immediately transferred to the institutional aquarium system filled with North Sea water $\left(\mathrm{SW}, 12{ }^{\circ} \mathrm{C}, 32\right.$ PSU) and pre-acclimated for at least 2 weeks. They were fed every other day either with a commercial algal blend (Nyos, PhytoMaxx) or a self-cultivated algal mixture containing Rhodomonas sp., Phaeodactylum tricornutum, Chaetocerus sp., and Isochrysis galbana. Prior to the experiments, epibionts were carefully removed and each oyster was measured, weighed and individually labelled.

\section{Experimental setup and water chemistry}

Randomized groups of labelled oysters were transferred to constant temperature rooms and incubated at $12{ }^{\circ} \mathrm{C}$ in recirculating aquarium systems as described in Schalkhausser et al. (2013). Briefly, the system consisted of header, receiver, and reservoir tanks and several experimental tanks, that were either populated with individual oysters (animals used for simultaneous recordings of heart rate, see below) or several oysters (15-20 oysters per $27 \mathrm{~L}$ tanks) later used for tissue sampling. Oxygenation in all flow-through tanks was kept $>90 \%$ by continuous aeration (see Table 1 ). Throughout all experiments, oysters were fed by regular addition of a self-cultivated algal mixture. Algal concentrations were maintained at a minimum of 3000 cells $\mathrm{mL}^{-1} \mathrm{SW}$. Every day, the experimental tanks were checked for mortality and faeces, and cleaned if necessary. After a 3 day pre-acclimation period to allow for recovery from handling, temperature was increased within $5 \mathrm{~h}$ overnight by $2{ }^{\circ} \mathrm{C}$ once every $48 \mathrm{~h}$ and kept at the targeted value $\pm 0.5^{\circ} \mathrm{C}$ (see Table 1) for $40-43 \mathrm{~h}$. Measurements were performed and samples taken at $14{ }^{\circ} \mathrm{C}$, $18^{\circ} \mathrm{C}, 22^{\circ} \mathrm{C}, 26^{\circ} \mathrm{C}, 30^{\circ} \mathrm{C}, 32{ }^{\circ} \mathrm{C}$, and $34{ }^{\circ} \mathrm{C}$, respectively. Heart rate was monitored online throughout exposure and analyzed for each $2{ }^{\circ} \mathrm{C}$ temperature step. After warming to $36^{\circ} \mathrm{C}$ all remaining oysters died within $18 \mathrm{~h}$. This protocol was run in triplicate.

Water temperature, salinity, partial pressures of oxygen $\left(\mathrm{PO}_{2}\right)$, and carbon dioxide $\left.\mathrm{PCO}_{2}\right)$ were monitored daily. $\mathrm{PO}_{2}$ was determined using $\mathrm{O}_{2}$-optodes (PreSens, Germany), and $P \mathrm{CO}_{2}$ was measured with a Vaisala device (Vaisala, Finland). The $\mathrm{pH}$ was measured using a $\mathrm{pH}$ electrode (InLab ${ }^{\circledR}$ Routine Pt1000, Mettler Toledo) calibrated with National Institute of Standards and Technology standard $\mathrm{pH}$ buffer solutions (National Bureau of Standards, NBS standards, Fisher Scientific). pH was converted to $\mathrm{pH}_{\text {Freescale }}$ (Waters and Millero 2013) as recommended in the guide for best practice in ocean acidification research (Riebesell et al. 2011). All devices were calibrated at the respective temperatures. The concentration of dissolved inorganic carbon (DIC) was determined using continuous flow analysis (CFA; QuAAtro, Seal Analytical) according to Stoll et al. (2001). Seawater carbonate chemistry parameters (total alkalinity, saturation state $(\Omega)$ for calcite, 
Table 1 Summary of water chemistry parameters during acute warming exposures

\begin{tabular}{|c|c|c|c|c|c|c|c|c|c|c|c|c|c|c|c|c|}
\hline \multirow{2}{*}{$\begin{array}{l}\mathrm{T}_{\text {Nominal }} \\
\left({ }^{\circ} \mathrm{C}\right)\end{array}$} & \multicolumn{2}{|l|}{$\mathrm{T}\left({ }^{\circ} \mathrm{C}\right)$} & \multicolumn{2}{|c|}{ Sal (SWU) } & \multicolumn{2}{|c|}{$\mathrm{pH}_{\text {Freescale }}$} & \multicolumn{2}{|c|}{$\begin{array}{l}\mathrm{PO}_{2}(\% \text { air } \\
\text { saturation })\end{array}$} & \multicolumn{2}{|c|}{$\mathrm{PCO}_{2}(\mu \mathrm{atm})$} & \multicolumn{2}{|c|}{ TA (mmol/kg SW) } & \multicolumn{2}{|c|}{$\Omega$ Aragonite } & \multicolumn{2}{|c|}{$\Omega$ Calcite } \\
\hline & Mean & $\pm \mathrm{SD}$ & Mean & $\pm \mathrm{SD}$ & Mean & $\pm \mathrm{S}$ & an & $\pm \mathrm{SD}$ & Mean & $\pm \mathrm{SD}$ & Mean & $\pm \mathrm{SD}$ & Mean & $\pm \mathrm{SD}$ & Mean & $\pm \mathrm{SD}$ \\
\hline 4 & 14.05 & 0.34 & 32.74 & 1.14 & 8.18 & 0.021 & & 1.09 & 40 & 36 & 26 & 141 & 3.02 & 0.17 & 4.73 & 0.26 \\
\hline 8 & 18.38 & 0.19 & 32.63 & 0.76 & 8.105 & 0.051 & 96.28 & 4.48 & 511 & 66 & 2629.19 & 194.07 & 2.88 & 0.49 & 4.47 & 0.76 \\
\hline 22 & 22.03 & 0.23 & 32.98 & 0.76 & 8.031 & 0.039 & 97.69 & 2.01 & 583 & 62 & 2390.51 & 10.83 & 2.51 & 0.19 & 3.85 & 0.30 \\
\hline 26 & 26.02 & 0.48 & 32.87 & 0.21 & 8.048 & 0.110 & 3 & 2.10 & 672 & 198 & 2321.84 & 150.92 & 2.62 & 0.81 & 3.97 & 1.24 \\
\hline 30 & 29.85 & 0.5 & 33.22 & 0.32 & 27 & 0.106 & 7 & 2.60 & 612 & 171 & 2.06 & 228.72 & 3.20 & 0.80 & 4.79 & 1.21 \\
\hline 32 & 32.10 & 0.47 & 33.43 & 0.21 & 7.99 & 0.10 & 0 & 3.24 & 718 & 177 & .16 & 264.50 & 3.11 & 0.84 & 4.68 & 1.25 \\
\hline 34 & 4.16 & 38 & 60 & 78 & 056 & 0.074 & 92.41 & 3.19 & 633 & 105 & 2517.92 & 179.30 & 3.95 & 0.74 & 5.83 & 1.09 \\
\hline
\end{tabular}

Temperature, salinity, $\mathrm{pH}_{\text {Freescale }}, \mathrm{PO}_{2}$, and $\mathrm{PCO}_{2}$ were determined in water samples collected throughout the exposures. The total alkalinity (TA), $\Omega$ Aragonite and $\Omega$ Calcite were calculated using $\mathrm{CO}_{2}$ sys software. Data are presented as mean $\pm \mathrm{SD}(\mathrm{n}=18-27)$

and aragonite) were calculated using CO2SYS software (Lewis and Wallace 1998) using barometric pressure values, as well as DIC, pH, temperature and salinity values determined for the respective day and temperature step. For calculations, we used K1 and K2 from Millero and DiTrolio (2010), the $\mathrm{KSO}_{4}$ dissociation constant from Dickson (1990), freescale for seawater $\mathrm{pH}$, and the $[\mathrm{B}]_{\mathrm{I}}$ value from Uppström (1974). Levels of nitrite, nitrate and ammonium were monitored and held below critical concentrations by regular SW exchanges, approximately twice a week. Detailed seawater physiochemical conditions at each temperature step are shown in Table 1.

\section{Filtration rate}

Since oysters retained the algae with $100 \%$ efficiency, filtration rates (FR) were calculated as the decrease of Rhodomonas sp. concentration over time standardized to soft body dry weight (DW) (Møhlenberg and Riisgård 1978; Nielsen et al. 2017). At each temperature step, the same individuals were placed in separate, temperature-controlled cylindrical $1 \mathrm{~L}$ tanks, and allowed to recover from handling stress for $1 \mathrm{~h}$ prior to the start of FR determination. Then, Rhodomonas sp. was added (final concentration 20,000 cells $\mathrm{mL}^{-1}$ to ensure sufficient algae provision for maximal FR) and samples were taken after 0,15 and $30 \mathrm{~min}$. Gentle bubbling during the experiment prevented the sedimentation of algal cells. Algal concentration was measured with a MultisizerTM 3 Coulter Counter (Beckman; USA) fitted with a $100 \mu \mathrm{m}$ aperture tube. Separate $1 \mathrm{~L}$ tanks fitted with shells only, served as controls for algal sedimentation, which was negligible. Directly after each animals' death, soft body mass was taken and dried for $48 \mathrm{~h}$ at $80{ }^{\circ} \mathrm{C}$.

The filtration rate (FR) was calculated according to Coughlan (1969) and is expressed as DW-specific rates $\left(\mathrm{L} \mathrm{h}^{-1} \mathrm{gDW}^{-1}\right)$ :
$\mathrm{FR}=\frac{V}{(t * n)} * \ln \frac{C_{0}}{C_{t}}: \mathrm{DW}$

where $V$ is the water volume of the experimental tank $(\mathrm{L}), t$ is the time (h), $\mathrm{n}$ is the number of individuals per tank (here, $\mathrm{n}=1$ ). $C_{0}$ and $C_{t}$ are the algal concentrations (cells $\mathrm{mL}^{-1}$ ) at time 0 and $t$, DW is the dry weight of the soft body mass (g).

\section{Heart rate}

Cardiac activity was measured using photo-plethysmography (Depledge and Andersen 1990; Zittier et al. 2015). The shell above the pericardium was sanded down carefully, and the plethysmograph (iSiTEC, Germany) was fixed (Pattex Ultra superglue, Germany). The signal was amplified (Type HBA100; iSiTEC, Germany) and recorded with the software LabChart (ADInstruments, Australia). HRs of eight oysters in total were monitored throughout exposure, during $36 \mathrm{~h}$ per temperature step. HR data (beats per min, bpm) were analyzed manually, excluding periods immediately after disturbances, such as the presence of researchers close to the experimental setup as well as low signal to noise ratios. This resulted in an analysis of 45 min recordings per temperature step using LabChart 8 Reader (ADInstruments, Australia). The whole plethysmograms of the $36 \mathrm{~h}$ recording were checked for pauses in the heart rate $(\geq 15 \mathrm{~min})$, which we defined as cardiac arrest (Fig. 1). Periods of cardiac arrest were expressed in $\%$ fractions of time in the total $36 \mathrm{~h}$ measurement period.

\section{Tissue sampling and metabolite extraction}

For tissue analyses, only open and ventilating oysters were randomly selected, weighed, and dissected on ice $(n=6-8)$. Oysters were checked regularly throughout the sampling day and only oysters that were open for at least 30 min prior to sampling were sacrificed. Tissues (gills, 
Fig. 1 Cardiac arrest of O. edulis. Red, dashed lines symbolize the onset and end of a cardiac arrest period. $Y$-axis illustrates the cardiac amplitude in voltage oscillations (V). Single spikes during the cardiac arrest periods are due to technical errors

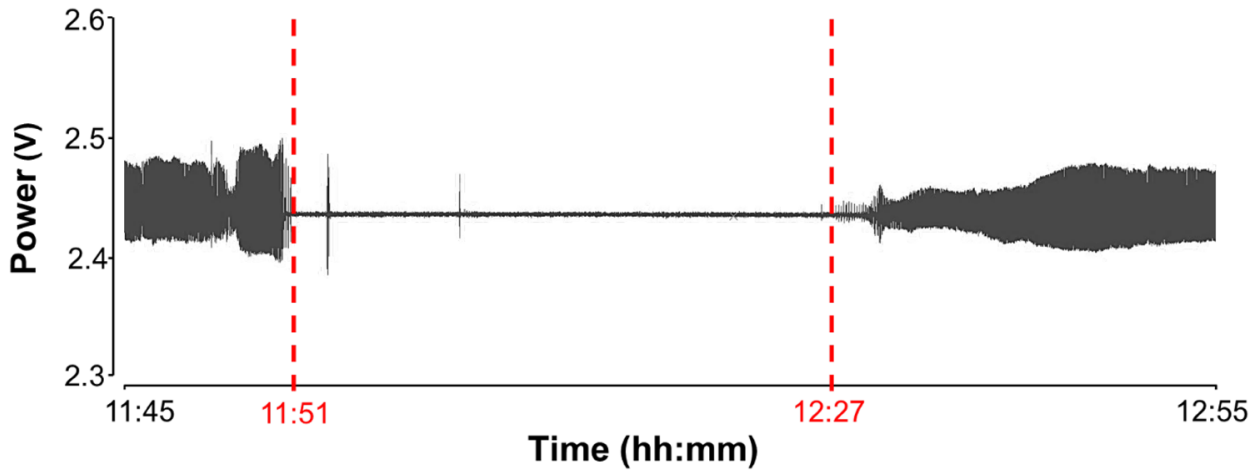

mantle, hepatopancreas, and muscle) were removed quickly, shock-frozen in liquid nitrogen, and stored at $-80{ }^{\circ} \mathrm{C}$ for further analyses. Gill metabolites were extracted using the methanol-chloroform extraction technique for small samples as described in Tripp-Valdez et al. (2017). Gill tissue (40-50 mg) were homogenized in ice-cold methanol $\left(8 \mathrm{~mL} \mathrm{~g}^{-1}\right.$ tissue $)$ and ice-cold MilliQ water $\left(2.5 \mathrm{~mL} \mathrm{~g}^{-1}\right.$ tissue) with Precellys 24 (Bertin Technologies, France) for $20 \mathrm{~s}$ at $6000 \mathrm{rpm}$ at $4{ }^{\circ} \mathrm{C}$. Thereafter, chloroform $\left(8 \mathrm{~mL} \mathrm{~g}^{-1}\right.$ tissue) and MilliQ ( $4 \mathrm{mLg}^{-1}$ tissue) were added. The homogenate was vortexed, incubated on ice for $10 \mathrm{~min}$, and centrifuged for $10 \mathrm{~min}$ at $3000 \mathrm{rpm}$ and $4{ }^{\circ} \mathrm{C}$. The upper methanol layer, containing polar metabolites, was used und dried using a SpeedVac at RT (RVC 2-33 IR, Christ GmbH, Germany) overnight. Dried pellets were stored at $4{ }^{\circ} \mathrm{C}$ until further analysis. Prior to analysis each pellet was re-suspended in a defined volume of deuterized water $\left(\mathrm{D}_{2} \mathrm{O}\right)$, twofold of the initial tissue weight. $\mathrm{D}_{2} \mathrm{O}$ contained $0.05 \mathrm{wt} \%$ of 3-(trimethylsilyl) propionic-2,2,3,3-d4 acid, sodium salt (TSP) (Sigma Aldrich, St. Louis, USA) as an internal standard and chemical shift reference. Final TSP concentration in each sample was $3.2 \mathrm{mM}$.

\section{Untargeted ${ }^{1} \mathrm{H}$ NMR-based metabolic profiling}

One-dimensional ${ }^{1} \mathrm{H}-\mathrm{NMR}$ spectroscopy was conducted in an ultra-shielded vertical 9.4 T NMR spectrometer (Advance III HD 400 WB, Bruker-BioSpin GmbH, Germany) using a high-resolution magic angle (HRMAS) probe for small volumes. The suspension was transferred into a standard $50 \mu \mathrm{l}$ zirconia on rotor of a triple tuneable ${ }^{1} \mathrm{H}_{-}{ }^{31} \mathrm{P}_{-}{ }^{31} \mathrm{C}$ HRMAS probe. Sample spinning rate was $3000 \mathrm{~Hz}$ at $20{ }^{\circ} \mathrm{C}$. TOPSPIN 3.2 software (TopSpin 3.2, Bruker-BioSpin GmbH, Germany) was used for acquisition. The NMR protocol comprised four different techniques as described in detail by Schmidt et al. (2017). The Call-Purcell-Meiboom-Gill (CPMG) sequence was used for metabolite analysis and quantification. Each spectrum was baseline, shim, and phase corrected and calibrated to the TSP signal with the software Chenomx NMR suite 8.1 (Chenomx Inc., Canada).
Thereafter, the ${ }^{1} \mathrm{H}-\mathrm{NMR}$ signals within each spectrum were assigned to metabolites by their chemical shifts using the Chenomx database. After assignment, the integration routine within Chenomx was used for metabolite quantification based on the TSP standard concentration. The concentrations of the proteinogenic branched chain amino acids valine, leucine, and isoleucine were summed for analysis.

\section{Statistical analysis}

The statistical analysis for temperature impacts on heart rate (HR) and filtration rate (FR) was performed with SigmaPlot 3.5 (Systat software Inc.). The temperature-induced changes in HR and FR were detected by one-way repeated ANOVA followed by a pairwise post-hoc Holm-Sidak test. An Arrhenius plot was used to detect discontinuities in the temperature-dependent slopes of HR and the Arrhenius break temperatures (ABTs) were calculated from intersections of linear regressions (Nickerson et al. 1989; Yeager and Ultsch 1989).

The temperature-dependent performance curve of $\mathrm{FR}_{\mathrm{F}}$ was fitted according to Schmalenbach et al. (2009):

$\mathrm{FR}_{F}(T)=A e^{-0.5\left(\frac{\ln \left(\frac{x}{x_{0}}\right)}{B}\right)^{2}}$,

where $A, B$ and $x_{0}$ are coefficients of variation and $x$ are FRs at ambient temperature.

The temperature-dependent performance curve of $\mathrm{HR}_{F}$ was fitted according to Pörtner and Knust (2007)

$H R_{F}(T)=F_{1}(T)+F_{2}(T)=\left(A_{1} e^{B_{1} T}+C_{1}\right)+\left(A_{2} e^{B_{2} T}+C_{2}\right)$,

$F_{1}(T)$ describes the temperature-dependent increase of HR until maximum. $F_{2}(T)$ represents the declining course in HR.

Gill metabolic profiles were analyzed for changes using Metaboanalyst (Metaboanalyst 3.6; Xia and Wishart 2016). Compound concentrations were normalized by generalized log-transformation for stabilizing the variance across 
metabolites as described by Purohit et al. (2004). Thereafter, a univariate one-way ANOVA followed by a Tukey's HSD was performed. The multivariate analysis comprised an unsupervised principle component analysis (PCA) aiming to find the directions that best explained the variance in the data set. Furthermore, we performed a supervised partial least-square discriminant analysis (PSL-DA) for class separation taking the weighted sum of squares of the PSL loadings (=Variable Importance in Projection; VIP) into account. The significance threshold was set to $P<0.05$.

\section{Results}

\section{Mortality}

Mortality of the oysters throughout exposure was negligible $(<7 \%)$ until $36^{\circ} \mathrm{C}$ was reached. The remaining oysters died during the first $18 \mathrm{~h}$ after reaching $36^{\circ} \mathrm{C}$.

\section{Filtration rate}

Filtration rates (FR) of $O$. edulis had an optimum between 18 and $26^{\circ} \mathrm{C}$ (Fig. 2; repeated one-way ANOVA, $F=8.10$, $\mathrm{DF}=6, P<0.001)$. Individuals varied more in absolute FR values at $26^{\circ} \mathrm{C}$ compared to other temperatures. Mean FR increased from $3.0 \pm 2.0 \mathrm{~L} \mathrm{~h}^{-1} \mathrm{gDW}^{-1}$ at $14{ }^{\circ} \mathrm{C}$ to a maximum of $7.7 \pm 4.5 \mathrm{~L} \mathrm{~h}^{-1} \mathrm{~g} \mathrm{DW}^{-1}$ at $22{ }^{\circ} \mathrm{C}$ followed by a progressive decrease resulting in a minimal $\mathrm{FR}$ of $0.3 \pm 0.3 \mathrm{~L} \mathrm{~h}^{-1} \mathrm{~g} \mathrm{DW}^{-1}$ at $34{ }^{\circ} \mathrm{C}$.

\section{Heart rate}

Heart rate (HR, Fig. 3) increased from $11.98 \pm 1.88 \mathrm{bpm}$ at $14{ }^{\circ} \mathrm{C}$ and reached $41.54 \pm 4.34 \mathrm{bpm}$ at $30^{\circ} \mathrm{C}$, with a mean linear increase of $1.85 \pm 0.70 \mathrm{bpm}{ }^{\circ} \mathrm{C}^{-1}$. Further warming from 30 to $36{ }^{\circ} \mathrm{C}$ decreased $\mathrm{HR}$ at a rate of $1.81 \pm 1.66 \mathrm{bpm}{ }^{\circ} \mathrm{C}^{-1}$ leading to an HR of $30.69 \pm 7.53 \mathrm{bpm}$ at $36{ }^{\circ} \mathrm{C}$. The calculated Arrhenius break temperature was
Fig. 2 Filtration rate (FR) of $O$. edulis. Each colored point indicates an individual. Boxplots show the variations of FR at the ambient temperature. Asterisk and horizontal line denote a significant difference of FRs at 18 , 22 and $26{ }^{\circ} \mathrm{C}$ from FRs at lower/ higher temperatures (repeated one-way ANOVA, Holm-Sidak Test, $F=8.10, P<0.001)$. Nonlinear regressions (dashed line) show the modelled FR after Schmalenbach et al. (2009):

$\operatorname{FR}_{F}(T)=8.487 e^{-0.5\left(\frac{\ln \left(\frac{x}{20.68}\right)}{0.25}\right)^{2}}$, $r 2=0.41 . \mathrm{n}=6-7$

Fig. 3 Impact of acute warming on heart rate (HR) of. O. edulis. HRs of individuals are indicated by different colors. Different letters indicate significant changes between temperature steps (repeated one-way ANOVA, Holm-Sidak Test, $F=96.86$, $P<0.001)$. Nonlinear regression after Pörtner and Knust (2007) is shown as dashed line: $\operatorname{HR}_{F}(T)=\left(10.83 * e^{0.06097 * T}\right.$

$+3.57 e 008)+(-0.0215$

$\left.* e^{0.2177 * T}-3.57 e 008\right)$ $r^{2}=0.90 . \mathrm{n}=4-8$
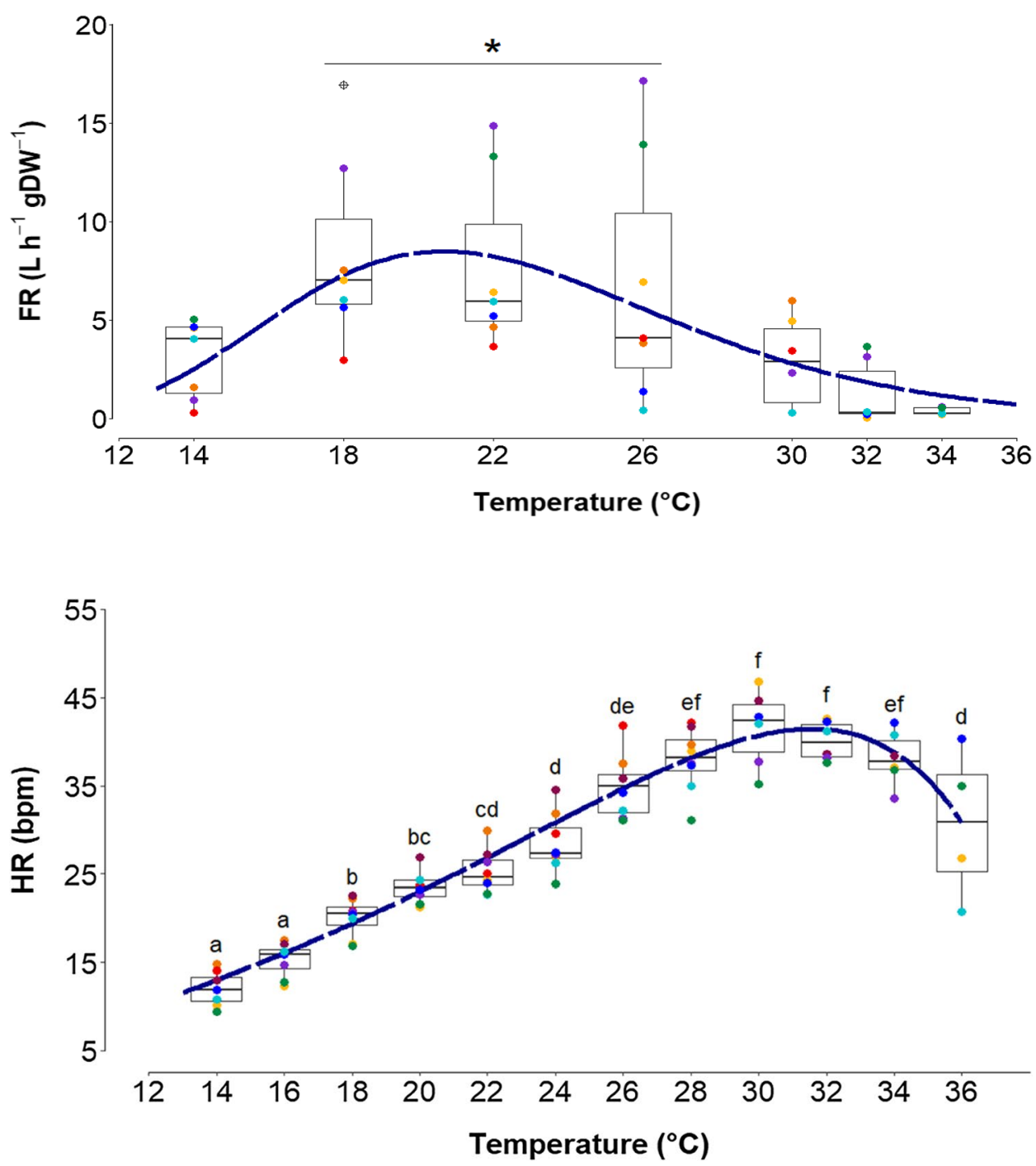
$30.33{ }^{\circ} \mathrm{C}$ (Fig. 4). From 14 to $26{ }^{\circ} \mathrm{C}$ HR showed a regular heart beat rhythm with increasing frequency and amplitude at increasing temperatures (Fig. 5a, b). At $28^{\circ} \mathrm{C}$ animals started to show temporary cardiac arrhythmia which was counterbalanced by high cardiac activity up to $30^{\circ} \mathrm{C}$ (Fig. 5c). The frequency of arrhythmia increased with rising temperatures, combined with a significantly reduced $\mathrm{HR}$ at $36{ }^{\circ} \mathrm{C}$ (repeated one-way ANOVA, $F=96.86, \mathrm{DF}=6$, $P<0.001)$.

Ostrea edulis showed temperature-dependent periods of cardiac arrest (Fig. 5d), which could be divided in three phases: From 14 to $22{ }^{\circ} \mathrm{C}$ the occurrence of cardiac arrests increased slightly from $0.2 \pm 0.1 \%$ to $1.3 \pm 0.3 \%$ of the recording time. At $24{ }^{\circ} \mathrm{C}$ and $26{ }^{\circ} \mathrm{C}$, cardiac arrests reached a maximum at $3.8 \pm 0.7 \%$ of total measurement time (one-way ANOVA, $F=16.154, \mathrm{DF}=11, P<0.001$ ). Above $26{ }^{\circ} \mathrm{C}$ cardiac arrest was rare and only observed at $32{ }^{\circ} \mathrm{C}$ $(0.15 \pm 0.06 \%)$ and $36^{\circ} \mathrm{C}(0.53 \pm 0.15 \%)$.

\section{Metabolites}

We identified 25 metabolites in the gill extracts of $O$. edulis (typical ${ }^{1} \mathrm{H}-\mathrm{NMR}$ spectrum shown in Fig. 6). Main compounds were osmolytes and amino acids. Organic osmolytes were taurine, betaine, trimethyl- $N$-oxide (TMAO) and homarine, with taurine and betaine exhibiting the highest concentrations in all spectra. Free amino acids were alanine, $\beta$-alanine, glutamine, glutamate, glycine, valine, isoleucine, leucine, lysine, arginine, homocysteine, and aspartate. Furthermore, we found signals of the adenylates such as ATP and ADP that were, however, not clearly distinguishable and three intermediates of the Krebs cycle: succinate, malate and fumarate, which are biomarkers for anaerobic metabolism. We further identified three membrane related intermediates sn-glycero-3-phosphocholine, choline, and $o$-phosphocholine.
UDP-glucose was the only sugar and key metabolite of the carbohydrate pathway identified. The singlet of acetate was assigned despite overlapping with arginine, lysine, and 4-aminobutyrate.

\section{Metabolite profiles under acute warming}

Principal component analysis did not indicate any specific outliers in the sample classes (data not shown). The class membership prediction by PLS-DA revealed that the gill metabolome of $O$. edulis was homogeneous in bivalves within the temperature range between $14{ }^{\circ} \mathrm{C}$ and $26{ }^{\circ} \mathrm{C}$ (Fig. 7a). The largest variance across the two principal components was found in the $26^{\circ} \mathrm{C}$ group indicating high heterogeneity between samples. Some individual profiles clustered closer to the profiles of samples taken at temperatures below $26{ }^{\circ} \mathrm{C}$, while others were closer to the cluster of samples taken at $34{ }^{\circ} \mathrm{C}$. The metabolome of $O$. edulis started to shift at $30{ }^{\circ} \mathrm{C}$ with a complete separation from all other clusters at $34^{\circ} \mathrm{C}$. The main metabolites explaining the PLS-DA projection (Fig. 7b) show the highest scores for the intermediates related to anaerobiosis such as fumarate, succinate and malate. The univariate analysis complements the PLS-DA results. Alanine, as a marker for early anaerobiosis, increased significantly from the initial value of $0.46 \pm 0.11 \mathrm{mM}$ at $14{ }^{\circ} \mathrm{C}$ to $0.84 \pm 0.23 \mathrm{mM}$ at $26{ }^{\circ} \mathrm{C}$, but showed no further increase with further warming (Fig. 8). The metabolites of late anaerobiosis (succinate, malate, and fumarate) remained at baseline levels $(0.02 \pm 0.01 \mathrm{mM}$ for succinate and fumarate, and $0.1 \pm 0.03 \mathrm{mM}$ for malate) until $22{ }^{\circ} \mathrm{C}$ was reached. At $26{ }^{\circ} \mathrm{C}$ all three metabolites increased significantly and reached their maximum concentration at $34{ }^{\circ} \mathrm{C}$ with $0.083 \pm 0.04 \mathrm{mM}$ (succinate), $0.36 \pm 0.27 \mathrm{mM}$ (malate), and $0.06 \pm 0.02 \mathrm{mM}$ (fumarate, $P \leq 0.001$ ).
Fig. 4 Arrhenius plot showing an impact of acute warming on heart rate (HR) of $O$. edulis. Arrhenius Break Temperature $(\mathrm{ABT})$ was analyzed from linear regression lines (dashed lines) intersecting at the respective breakpoint with $f(\log$ HR 14 $\left.30{ }^{\circ} \mathrm{C}\right)=11.0559+(-2.8519$ $\times$ Temp), $r^{2}=0.97, P<0.001$; and $\mathrm{f}\left(\log \mathrm{HR} 32-36{ }^{\circ} \mathrm{C}\right)=-8.3$ $74+(3.049 \times \mathrm{Temp}), r^{2}=0.87$, $P=0.2308 . \mathrm{n}=4-8$

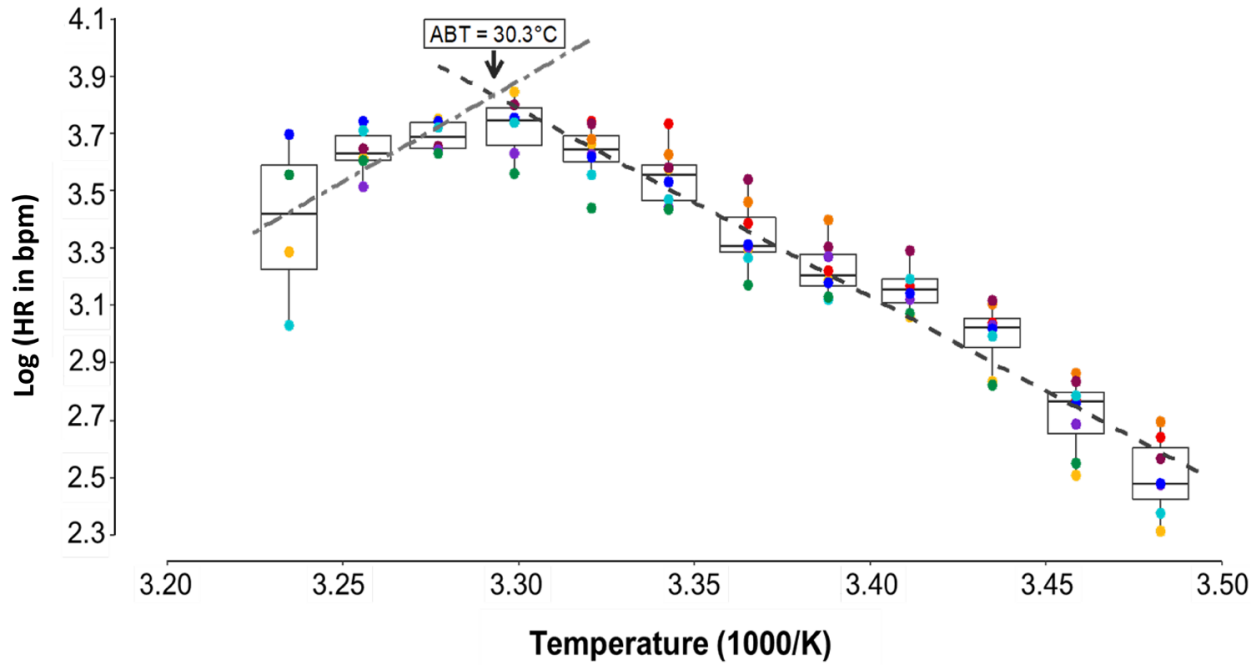


Fig. 5 Impact of acute warming on cardiac performance of O.edulis. a Rhythmic heartbeat at $14{ }^{\circ} \mathrm{C}$ and $\mathbf{b}$ rhythmic heartbeat at $26^{\circ} \mathrm{C}$, c distinctly arrhythmic heartbeat at $30^{\circ} \mathrm{C}$, d fractions of cardiac arrest periods in total measurement time $(36 \mathrm{~h})$ at each temperature step. HR pauses were defined as cardiac arrest periods of at least $15 \mathrm{~min}$. Asterisk denotes significant differences among temperature steps (one-way ANOVA, Holm-Sidak Test, $F=16.154, P<0.001)$. Data are means $\pm \mathrm{SE}, \mathrm{n}=4-8$ (a)

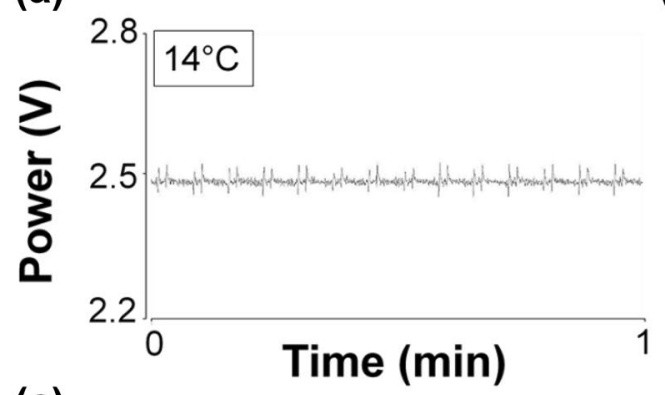

(c)

(b)

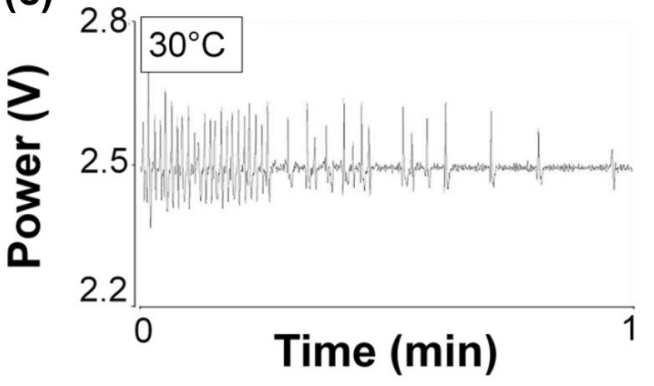

(d)

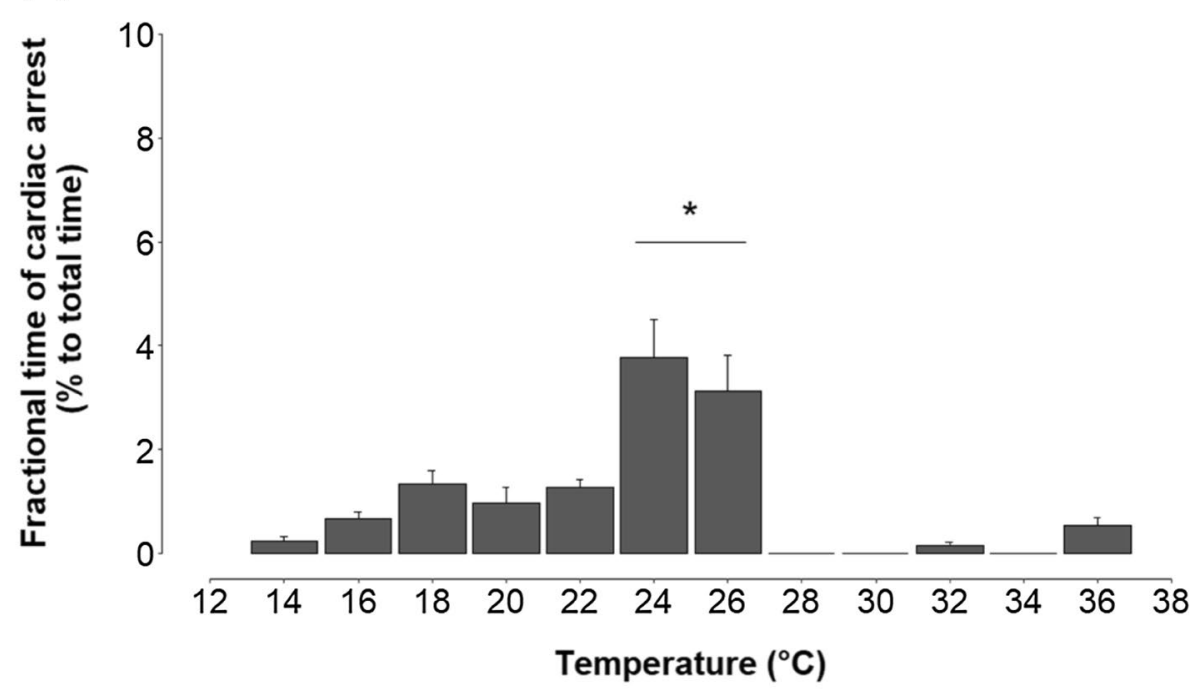

\section{Discussion}

\section{Filtration and heart rates}

We investigated the response of the European flat oyster, O. edulis, to acute warming. Following the OCLTT concept, we aimed to depict the acute thermal tolerance window of $O$. edulis by linking performance indicators, filtration rate (FR), heart rate (HR) and hence, indirectly, oxygen supply, while identifying the thermal constraints to aerobic metabolic performance, as determined from cellular markers for anaerobiosis. In combination with an in-depth-analysis of cardiac online recordings, the present data suggest not only a physiological, but also a behavioral change of $O$. edulis exposed to warming.

For comparison to literature data, it is important to be sure that FR is determined under optimal conditions, considering methodological, abiotic, and biotic aspects which ensure that bivalves are fully open, and thus, display maximal filtration (Riisgård 2001). FR increased linearly with warming as long as the animals were within their window of thermal tolerance as identified in literature studies (Kittner and Riisgård 2005; Riisgård et al. 2003). Beyond such limits, FR dropped in association with a progressive reduction in valve gape (Jørgensen et al. 1990; Kittner and Riisgård 2005). Overall, the FR of O. edulis followed a temperaturedependent bell shaped curve between 14 and $36{ }^{\circ} \mathrm{C}$. Similar 


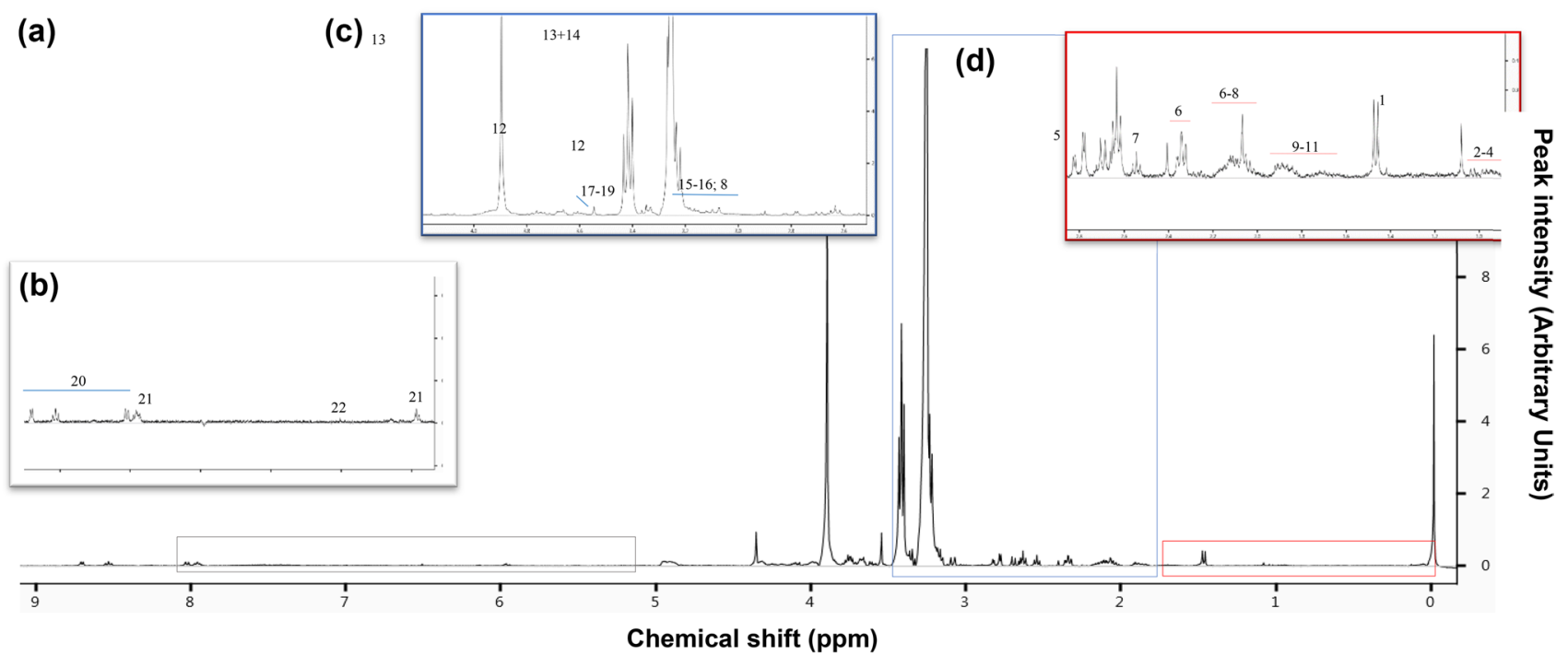

Fig. 6 Representative spectrum of gill metabolites depicted in a onedimensional $400 \mathrm{MHz}$ CPMG ${ }^{1} \mathrm{H}-\mathrm{NMR}$ spectrum of a tissue extract from O.edulis sampled at $34{ }^{\circ} \mathrm{C}$. a Shown are the entire spectra and b-d enlarged areas of this spectrum with identified metabolites. Keys: Alanine (1); Valine (2); Isoleucine (3); Leucine (4); Succinate
(5); Glutamate (6); Glutamine (7); Homocysteine (8); Arginine (9); Lysine (10); Acetate (11); Taurine (12); Betaine (13); Trimethylamide-N-oxide (TMAO; 14); Aspartate (15); Hypotaurine (16); Choline (17); O-Phosphocholine (18); Sn-Glycero-3phosphocholine (19); Homarine (20); UDP-Glucose (21); Triphosphate (22) (a)

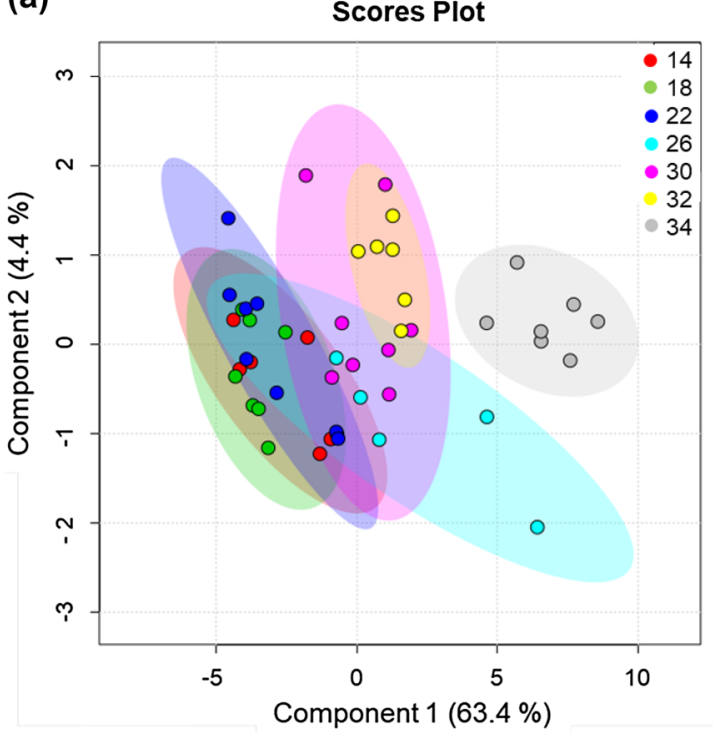

Fig. 7 Impact of acute warming on the metabolic profile of gill tissue from $O$. edulis. a Score Plot of the PLS-DA model for the normalized concentrations of assigned gill tissue metabolites found in O. edulis sampled at $14{ }^{\circ} \mathrm{C}, 18{ }^{\circ} \mathrm{C}, 22{ }^{\circ} \mathrm{C}, 26{ }^{\circ} \mathrm{C}, 30{ }^{\circ} \mathrm{C}, 32{ }^{\circ} \mathrm{C}$, and

curves were described by Widdows (1976) for Mytilus edulis between 10 and $28{ }^{\circ} \mathrm{C}$ and by Petersen et al. (2003) for Arctic clams, Hiatella arctica and Mya sp. between -1 and $11^{\circ} \mathrm{C}$. O. edulis filtered at maximum rates between 18 and $26{ }^{\circ} \mathrm{C}$ reaching on average $7.7 \pm 4.5 \mathrm{~L} \mathrm{~h}^{-1} \mathrm{gDW}^{-1}$, which is comparable to the $7.3 \pm 1.7 \mathrm{~L} \mathrm{~h}^{-1} \mathrm{gDW}^{-1}$ at $22{ }^{\circ} \mathrm{C}$ when

(b)

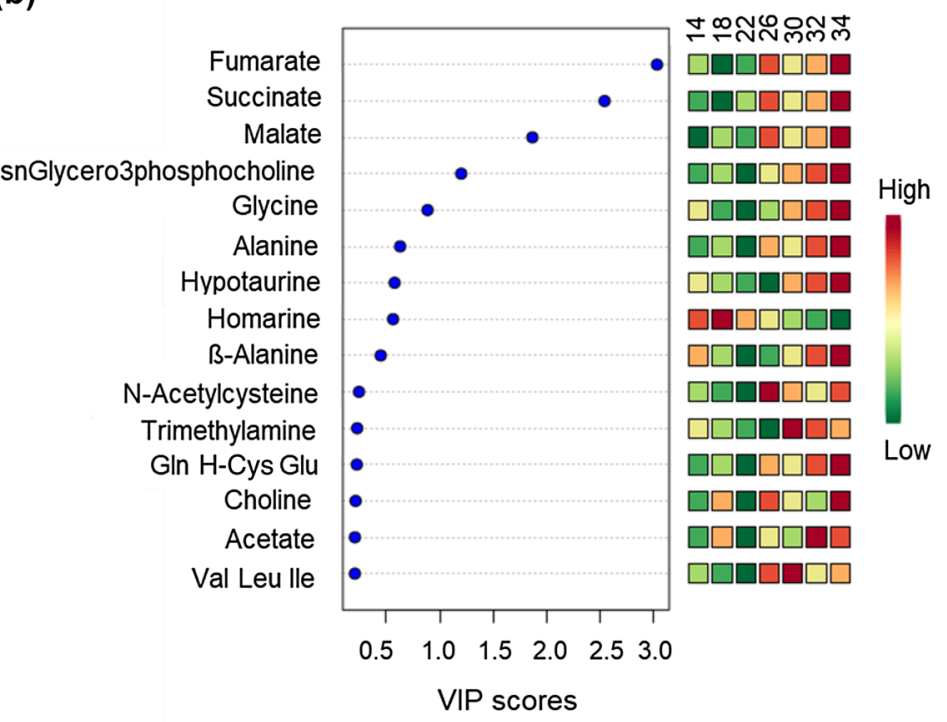

$34{ }^{\circ} \mathrm{C}$. Ellipses correspond to a confidence interval of $95 \%$. b Variable Importance in Projection (VIP) are the weighted sum of squares of the PLS loadings

using Rhodomonas cultures (Nielsen et al. 2017). Notably, three out of seven individuals showed impaired FR at $26{ }^{\circ} \mathrm{C}$ suggesting a constraining temperature (see "Discussion").

Temperature-dependent changes in the HR of $O$. edulis revealed a warming-induced limitation at higher temperatures than those observed for FR. An Arrhenius break point 
Early anaerobiosis
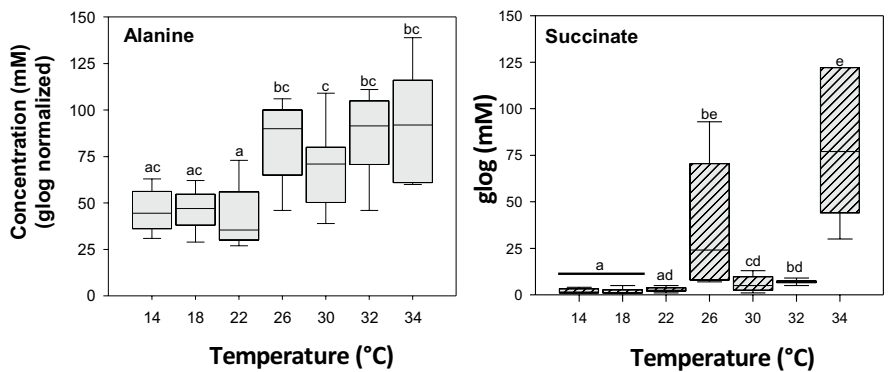

Late anaerobiosis

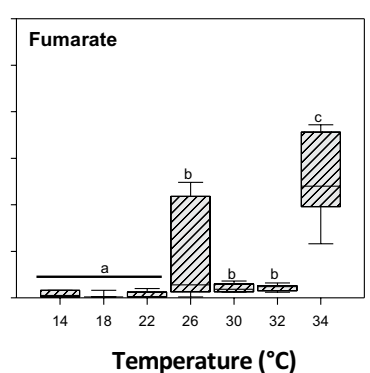

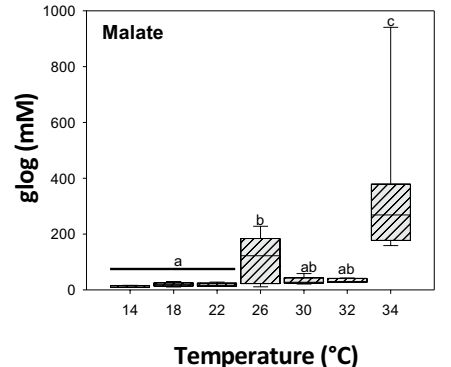

Fig. 8 Impact of acute warming on the levels of gill metabolites in O. edulis. Concentrations ( $\mathrm{mM}$ ) were glog transformed, normalized and analyzed by one-way ANOVA, followed by a post-hoc test. Sig- nificant differences between data are indicated by different letters $(P<0.05)$. Data are shown as box plots, $\mathrm{n}=5-8$ temperature $(\mathrm{ABT})$ of $\mathrm{HR}$ was reached at $30{ }^{\circ} \mathrm{C}$. Close to the ABT, we observed onset of cardiac arrhythmia occurring from $28^{\circ} \mathrm{C}$ onwards. Warming-induced loss of rhythmic HR has previously been shown for other bivalves (Trueman and Lowe 1971; Braby and Somero 2006; Xing et al. 2016). While monitoring HR we observed infrequent periods of cardiac arrest. Nearly complete suppression of HR occurs with some delay upon valve closure in bivalves (Trueman and Lowe 1971; Lannig et al. 2008).

Notably, at the lower exposure temperatures $\left(14-22{ }^{\circ} \mathrm{C}\right)$, we observed cardiac arrest periods in $O$. edulis that may reflect the natural, rhythmic opening/closure behavior of bivalves. For example, Ortmann and Grieshaber (2003) monitored valve movements of the Asian clam, Corbicula fluminea, over a period of 2 years, and showed that valve opening/closure followed a circadian rhythm during summer.

Progressive warming of $O$. edulis led to extended periods of cardiac arrest at $24{ }^{\circ} \mathrm{C}$ and $26^{\circ} \mathrm{C}$, possibly reflecting a behavioral response to less favorable conditions by extended valve closure. During winter season, when temperature $\left(<5^{\circ} \mathrm{C}\right)$ and food availability were very low, Asian clams also showed extended closure periods of several days (Ortmann and Grieshaber 2003). Mytilus galloprovincialis remained open for approximately $90 \%$ of the time under favorable conditions and closed its valves for up to $50 \%$ of the time when temperatures became unfavorable (Anestis et al. 2007). Benefits for immersed bivalves to remain closed during intervals of poor algal supply or hypoxia are mainly interpreted as energy saving strategies, since upon closure metabolic rate (SMR) is reduced (Jørgensen et al. 1986; Ortmann and Grieshaber 2003; Sokolova et al. 2012; Riisgård and Larsen 2015). However, further warming will cause energy demand to rise with oxygen consumption increasing steadily without leveling off (Newell et al. 1977; Shumway and Koehn 1982; Haure et al. 1998). Accordingly, periods of cardiac arrests ceased in $O$. edulis above $26{ }^{\circ} \mathrm{C}$, paralleled by an opening of the shell (personal observations) that enables aerobic metabolism to fuel most if not all of the rising energy demand. Previous studies have shown that increasing acclimation temperature elevated the respiratory time activity (RTA, fractional time that animals spend open, ventilating actively) in the Eastern oyster, Crassostrea virginica (Lannig et al. 2006). Similarly, periods of cardiac arrest became scarce at temperatures of $28^{\circ} \mathrm{C}$ and beyond in $O$. edulis indicating a disruption of the normal valve closing pattern in response to warming for increased oxygen uptake to cover high cellular energy demand.

\section{Mode of metabolism}

The main cellular response to warming beyond $26^{\circ} \mathrm{C}$ was an increase in the levels of anaerobic metabolites indicating an onset of anaerobiosis with levels peaking shortly before death of the organisms at $34^{\circ} \mathrm{C}$. Anaerobic end product concentrations (e.g., succinate, acetate, or propionate) are highly variable depending on preferred anaerobic pathways; they may also depend on tissue (anaerobic pathways of bivalves reviewed by De Zwaan and Wijsmann 1976; Livingstone 1991; Müller et al. 2012). In gill tissues of $O$. edulis, succinate was the predominant anaerobic end product. We observed a significant rise of anaerobic end products at $26^{\circ} \mathrm{C}, 10^{\circ} \mathrm{C}$ below the lethal temperature. Interestingly, oysters sampled at this temperature were most diverse in their branchial metabolomic profiles as indicated by the PLSDA model. Here, the individuals clustered either closer to profiles of lower temperature groups (= performing better), while two samples were closer to the metabolomic pattern found at $34{ }^{\circ} \mathrm{C}$ (= performing worse).

The onset of anaerobiosis at $26{ }^{\circ} \mathrm{C}$ paralleled the increased cardiac arrest times and may be a response to valve closure and associated oxygen deficiency, as part of the energy saving strategy. In contrast to alanine levels (early anaerobiosis) which remained stable beyond $26{ }^{\circ} \mathrm{C}$, those of succinate (fumarate and malate) showed 
a second, more drastic rise at $34{ }^{\circ} \mathrm{C}$, thereby indicating severe oxygen deficiency, due to an increase in branchial energy demand, cutting back on time for survival. Indeed, further warming to $36{ }^{\circ} \mathrm{C}$ resulted in death of all animals.

The average annual SW temperatures in NW Spain (Galicia), where the oysters were collected ranges between 11 and $21{ }^{\circ} \mathrm{C}$ with temperatures above $16{ }^{\circ} \mathrm{C}$ between May and November (Pazos et al. 1997; www.seatemperature. org). Aquaculture oysters are raft cultured in the estuary and experience the same environmental parameters as wild oysters. Our data indicate an optimal temperature range for the Spanish oyster population between 18 and $24{ }^{\circ} \mathrm{C}$ suggested by moderate, rhythmic HR and maximal filtration (Fig. 9) consistent with the prevailing summer temperatures in oyster' habitat. Similarly, a study of the brown mussel Perna perna from the Gulf of Mexico, revealed a long-term upper tolerance limit at around $30{ }^{\circ} \mathrm{C}$, congruent with the ambient seasonal SW temperature (Hicks and McMahon 2002).

Notably, European oysters displayed a broad temperature span of $10{ }^{\circ} \mathrm{C}$ between $\mathrm{T}_{\text {crit }}$ and the lethal temperature, while other studies showed this range to be much narrower. For example, the temperate sublittoral king scallop, Pecten maximus displayed an upper limit to its thermal optimum at around $25{ }^{\circ} \mathrm{C}$ (Artigaud et al. 2014), and reached the lethal temperature at $26-28{ }^{\circ} \mathrm{C}$ (Götze et al. in review). One reason might be, that oysters, being adapted to a highly variable environment, have a broad passive tolerance range to endure abiotic challenges beyond the optimum (Pörtner et al. 2017). This is in agreement with studies showing that the upper thermal tolerance limit of bivalves correlates significantly with habitat (littoral vs. sublittoral) and tidal height distribution (e.g., Wilson 1981; Wilson and Elkaim 1991).
While temperature-induced changes in oxygen consumption and heart rates are positively correlated in marine invertebrates (Marshall and McQuaid 1992; Schiffer et al. 2014; Bakhmet 2017) our data suggest moderate metabolic costs for $O$. edulis within its thermal optimum. Hence, the thermal limit to HR is not yet reached, leaving some room for an increase in aerobic metabolism, a conclusion supported by an $\mathrm{ABT}$ at around $30^{\circ} \mathrm{C}$. According to Guderley and Pörtner (2010), maintenance costs (measured as standard metabolic rate $=$ SMR) are moderate within the optimum range and fully covered by aerobic metabolism; this is paralleled by a maximum scope for growth, with sufficient energy being provided by the aerobic power budget. Furthermore, in NW Spain the predominant phytoplankton blooms occur from May to September (Bode et al. 2005). During these months with ample food supply and favorable ambient temperatures, O. edulis should have a high net gain in body weight. Indeed, earlier studies showed that the scope for growth was maximal at around $15^{\circ} \mathrm{C}$ (Newell et al. 1977; Buxton et al. 1981). Accordingly, O. edulis spends most of the year at temperatures within its active thermal tolerance range (Pörtner et al. 2017).

The progressive rise in $\mathrm{HR}$ above $22^{\circ} \mathrm{C}$ when FR starts to level off indicates a rise in baseline aerobic energy demand which increasingly constrains aerobic performance. This is in line with the study of Buxton et al. (1981) showing that between 20 and $25{ }^{\circ} \mathrm{C}$ filtration efficiency declined, while oxygen demand still rose, resulting in a shrinking scope for growth. Consequently, a reduction in valve gape might be a behavioral response to limit food intake and thus digestion costs as maintenance costs rise. This might indicate that $O$. edulis has reached the upper pejus temperature range of OCLTT (conditions getting worse; Pörtner et al. 2017).

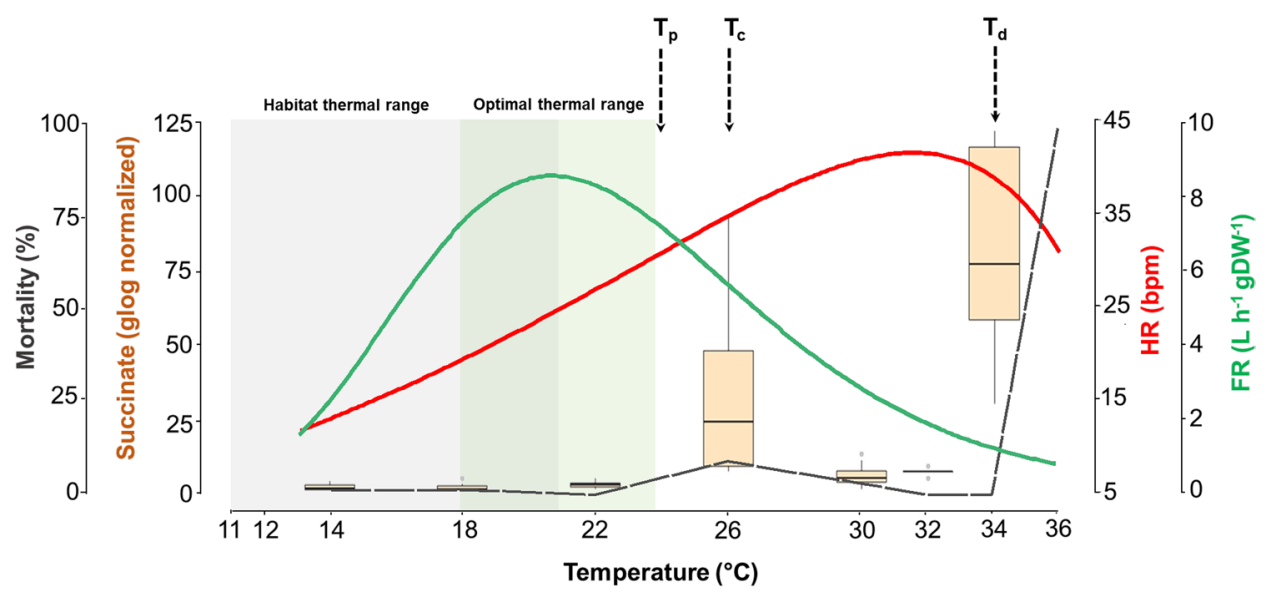

Fig. 9 Acute thermal window of O.edulis integrating temperaturedependent mortality (black), temperature-induced changes in filtration rate (FR, green), heart rate (HR, red) and succinate levels (mM, glog transformed) in gills as an anaerobic biomarker (boxplot). The annual habitat temperature range is highlighted in grey. The derived optimal temperature range is marked in green. Dashed black arrows indicate putative values of $T_{\mathrm{p}}$ (pejus temperature), $T_{\mathrm{c}}$ (critical temperature) and $T_{\mathrm{d}}$ (deadly temperature) 
Further warming $\left(\geq 26^{\circ} \mathrm{C}\right)$ emphasized performance limitations as indicated by a significantly reduced FR, the onset of cardiac dysfunction (e.g., arrhythmia) and paralleled by the accumulation of anaerobic end products. According to OCLTT, the onset of anaerobiosis indicates that an organism surpasses the critical temperature $\left(\mathrm{T}_{\text {crit }}\right)$, where survival becomes strictly time-limited due to the mismatch between aerobic energy demand and supply (Pörtner et al. 2017). Gill metabolism indicates $\mathrm{T}_{\text {crit }}$ being surpassed from $26^{\circ} \mathrm{C}$ onwards, several degrees below the temperature threshold for cardiac dysfunction. Accordingly, gill functioning seems to be a more sensitive thermal stress indicator than HR. This can be explained by the high metabolic activity and energy demand of gills (see "Discussion"). In its natural environment, $O$. edulis might undergo partial anaerobiosis at this temperature $\left(26^{\circ} \mathrm{C}\right)$; at the same time the species can survive in a time-dependent manner as indicated by the rhythmic and not yet fully maximized heart rate. This response and associated metabolic depression may support extended passive survival of $O$. edulis. Finally, arrhythmia and an ABT setting in at around $28-30{ }^{\circ} \mathrm{C}$ indicate diminished $\mathrm{O}_{2}$ distribution to tissues associated with limited circulatory performance, and accordingly, cardiac failure corroborating that the upper thermal limit has been reached (Somero 2002). While in other species $\mathrm{T}_{\text {crit }}$ and cardiac $\mathrm{ABT}$ are similar cardiac $\mathrm{ABT}$ of the oyster is shifted to higher temperatures within the passive tolerance range. Furthermore, anaerobiosis as an alternative energy supply also supports passive survival (Pörtner 2001; Han et al. 2017) until finally a lethal temperature is reached at $36{ }^{\circ} \mathrm{C}$.

\section{Outlook}

Our results indicate that $O$. edulis in NW Spain lives currently largely within its thermal optimum range. This population, however, might be negatively affected in the course of projected ocean warming. SW temperatures exceeding $26^{\circ} \mathrm{C}$ may constrain oyster performance unless acclimatization occurs. Elevated temperatures may also make oysters susceptible to bacterial and viral infection (Zannella et al. 2017), leading to altered species composition of communities that may contribute to weaken the European oyster populations (Poloczanska et al. 2013). Further research is needed to understand the long-term effects of thermal stress on this species, and to what extent and how $O$. edulis is able to resist the warming trend. One crucial factor of resilience is set by the cellular capacity to maintain cellular homeostasis and integrity. Temperature stress induces cellular protective responses such as upregulation of, e.g., heat shock proteins, or antioxidant pathways, which demand energy and diminish growth or reproduction. The sum of cellular protection mechanisms is defined as the capacity of passive tolerance, which is strictly time-limited (Pörtner 2010).
Therefore, one crucial aspect of further research will be to understand the passive capacity of $O$. edulis and how it is influenced as well as exploited during combined exposures to warming, oxygen deficiency and increased $\mathrm{CO}_{2}$ levels. The combined capacities of both active and passive tolerance mechanisms may influence the selective survival of species under climate change and associated extreme conditions and may thereby shape related changes in community composition (see introduction). If such principles hold for ongoing climate change they may also have been operative during climate driven evolutionary crises in Earth history.

Acknowledgements This study was funded by the Deutsche Forschungsgemeinschaft (DFG Po278/16-1) and is embedded in the Research Unit TERSANE (FOR 2332: Temperature-related stressors as a unifying principle in ancient extinctions). We thank I. Ketelsen, F. Feliz Moraleda, and R. Gorniak for technical support and assistance during the exposures and animal care. Furthermore, we want to thank the section Marine BioGeoScience, in particular S. Trimborn, A. Terbrüggen and T. Brenneis for providing access to the Coulter Counter and the Observer microscope. We thank the Biological station of Toralla (ECIMAT, Spain), in particular A.Villanueva and D. Costas for support in animal supply.

\section{Compliance with ethical standards}

This study was funded by the Deutsche Forschungsgemeinschaft (DFG Po278/16-1).

Conflict of interest Authors declare that they have no conflict of interest.

Ethical approval All applicable international, national, and/or institutional guidelines for the care and use of animals were followed.

\section{References}

Anestis A, Lazou A, Pörtner H-O, Michaelidis B (2007) Behavioral, metabolic, and molecular stress response of marine bivalve Mytilus galloprovincialis during long-term acclimation at increasing ambient temperature. Am J Physiol Regul Integr Comp Physiol 293:911-921. https://doi.org/10.1152/ajpregu.00124.2007

Artigaud S, Lacroic C, Pichereau V, Flye-Sainte-Marie J (2014) Respiratory response to combined heat and hypoxia in the marine bivalves Pecten maximus and Mytilis spp. Comp Biochem Physiol A 175:135-140. https://doi.org/10.1016/j.cbpa.2014.06.005

Bakhmet IN (2017) Cardiac activity and oxygen consumption of the blue mussel (Mytilus edulis) from the White Sea in relation to body mass, ambient temperature and food availability. Polar Biol 40:1959-1964. https://doi.org/10.1007/s00300-017-2111-6

Bambach RK, Knoll AH, Wang SC (2004) Origination, extinction, and mass depletions of marine diversity. Paleobiology 30:522-542. https://doi.org/10.1666/0094-8373(2004)030\%3c0522:OEAMD $\mathrm{O} \% 3 \mathrm{e} 2.0 . \mathrm{CO} ; 2$

Bertolino M, Betti F, Bo M, Cattaneo-Vietti R, Pansini M, Romero J, Bavestrello G (2015) Changes and stability of a Mediterranean hard bottom benthic community over 25 years. J Mar Biol Assoc UK 96:341-350. https://doi.org/10.1017/S0025315415001186

Beukema JJ, Dekker R, Jansen JM (2009) Some like it cold: populations of the tellinid bivalve Macoma balthica (L.) suffer in various 
ways from a warming climate. Mar Ecol Prog Ser 384:135-145. https://doi.org/10.3354/meps07952

Bode A, Álvarez-Ossorio T, González N, Lorenzo J, Rodríguez C, Varela M, Varela MM (2005) Seasonal variability of plankton blooms in the Ria de Ferrol (NW Spain): II. Plankton abundance, composition and biomass. Estuar Coast Shelf Sci 63:285-300. https://doi.org/10.1016/j.ecss.2004.11.021

Braby CE, Somero GN (2006) Following the heart: temperature and salinity effects on heart rate in native and invasive species of blue mussels (genus Mytilus). J Exp Biol 209:2554-2566. https://doi. org/10.1242/jeb.02259

Brinkhoff W, Stöckmann K, Grieshaber M (1983) Natural occurence of anaerobiosis in molluscs from intertidal habitats. Oecol 57:151155. https://doi.org/10.1007/BF00379573

Buxton CD, Newell RC, Field JG (1981) Response-surface analysis of the combined effects of exposure and acclimation temperatures on filtration, oxygen consumption and scope for growth in the oyster Ostrea edulis. Mar Ecol Prog Ser 6:73-82. https://doi. org/10.3354/meps006073

Calosi P, De Witt P, Thor P, Dupont S (2016) Will life find a way? Evolution of marine species under global change. Evol Appl 9:1035-1042. https://doi.org/10.1111/eva.12418

Cattaneo-Vietti R (2018) Structural changes in Mediterranean marine communities: lessons from the Ligurian Sea. Rend Fis Acc Lincei 29:515-524. https://doi.org/10.1007/s12210-018-0670-2

Coughlan J (1969) The estimation of filtering rate from the clearance of suspensions. Mar Biol 2(4):356-358

De Zwaan A, Wijsmann TCM (1976) Anaerobic metabolism in bivalvia (mollusca) — characteristics of anaerobic metabolism. Comp Biochem Physiol B 54:313-324. https://doi.org/10.1016/03050491(76)90247-9

Depledge M, Andersen B (1990) A computer-aided physiological monitoring system for continuous, long-term recording of cardiac activity in selected invertebrates. Comp Biochem Physiol A 96:473-477. https://doi.org/10.1016/0300-9629(90)90664-E

Dickson AG (1990) Standard potential of the $\left(\mathrm{AgCl}(\mathrm{s})+1 / 2 \mathrm{H}_{2}(\mathrm{~g})=\mathrm{Ag}\right.$ (s) $+\mathrm{HCl}(\mathrm{aq})$ ) cell and the dissociation constant of bisulfate ion in synthetic sea water from 273.15 to $318.15 \mathrm{~K}$. J Chem Thermodyn 22:113-127

Domnik NJ, Polymeropoulos ET, Elliott NG, Frappell PB, Fisher JT (2016) Automated non-invasive video-microscopy of oyster spat heart rate during acute temperature change: impact of acclimation temperature. Front Physiol 7:236. https://doi.org/10.3389/fphys 2016.00236

Finnegan S, Anderson SC, Harnik PG, Simpson C, Tittensor DP, Byrnes JE, Finkel ZV, Lindberg DR, Liow LH, Lockwood R, Lotze HK, McClain CR, McGuire JL, O'Dea A, Pandolfi JM (2015) Paleontological baselines for evaluating extinction risk in the modern oceans. Science 348:567-570. https://doi.org/10.1126/ science.aaa6635

Frederich M, Pörtner H-O (2000) Oxygen limitation of thermal tolerance defined by cardiac and ventilatory performance in spider crab, Maja squinado. Am J Physiol Regul Integr Comp 279:R1531-R1538. https://doi.org/10.1152/ajpre gu.2000.279.5.R1531

Garrabeu J, Coma R, Bensoussan N et al (2009) Mass mortality in Northwestern Mediterranean rocky benthic communities: effects of the 2003 heat wave. Global Change Biol 15:1090-1103. https ://doi.org/10.1111/j.1365-2486.2008.01823.x

Giomi F, Pörtner H-O (2013) A role for haemolymph oxygen capacity in heat tolerance of eurythermal crabs. Front Physiol 4:110. https ://doi.org/10.3389/fphys.2013.00110

Götze S, Bock C, Eymann C, Lannig G, Steffen J, Pörtner H-O (2020) Single and combined effects of the "Deadly trio" hypoxia, hypercapnia and warming on the cellular metabolism of the great scallop Pecten maximus. Comp Biochem Physiol B (in review)

Guderley H, Pörtner H-O (2010) Metabolic power budgeting and adaptive strategies in zoology: examples from scallops and fish. Can J Zool 88:753-763. https://doi.org/10.1139/Z10-039

Guo X, Li C, Wang H, Xu Z (2018) Diversity and evolution of oysters. J Shellfish Res 37:755-771. https://doi.org/10.2983/035.037.0407

Han G, Zhang S, Dong Y (2017) Anaerobic metabolism and thermal tolerance: the importance of opine pathways on survival of a gastropod after cardiac dysfunction. Integr Zool 12:361-370. https ://doi.org/10.1111/1749-4877.12229

Haure J, Penisson C, Bougrier S, Baud J (1998) Influence of temperature on clearance and oxygen consumption rates of the flat oyster Ostrea edulis: determination of allometric coefficients. Aquaculture 169:211-224. https://doi.org/10.1016/S0044-8486(98)00383 $-4$

Hicks DW, McMahon RF (2002) Respiratory responses to temperature and hypoxia in the nonindgenous Brown Mussel, Perna perna (Bivalvia. Mytilidae) from the Gulf of Mexico. J Exp Mar Biol Ecol 277:61-78. https://doi.org/10.1016/S0022-0981(02)00276-9

Hochachka PW, Somero GN (2002) Biochemical adaptation: mechanism and process in physiological evolution. Oxford University Press, New York, p 480 (ISBN 0-195-11702-6)

Hoegh-Guldberg O, Bruno JF (2010) The impact of climate change on the world's marine ecosystems. Science 328:1524-1528. https:// doi.org/10.1126/science.1189930

Joachimski MM, Lai X, Shen S, Jiang H, Luo G, Chen B, Chen J, Sun Y (2012) Climate warming in the latest Permian and the Permian-Triassic mass extinction. Geology 40:195-198. https:// doi.org/10.1130/G32707.1

Jørgensen CB, Møhlenberg F, Sten-Knudsen O (1986) Nature of relation between ventilation and oxygen consumption in filter feeders. Mar Ecol Prog Ser 29:73-88. https://doi.org/10.3354/meps029073

Jørgensen CB, Larsen PS, Riisgård HU (1990) Effects of temperature on the mussel pump. Mar Ecol Prog Ser 64:89-97

Kittner C, Riisgård HU (2005) Effect of temperature on filtration rate in the mussel Mytilus edulis: no evidence for temperature compensation. Mar Ecol Prog Ser 305:147-152. https://doi.org/10.3354/ meps 305147

Knoll AH, Bambach RK, Payne JL, Pruss S, Fischer WW (2007) Paleophysiology and end-Permian mass extinction. EPSL 256:295-313. https://doi.org/10.1016/j.eps1.2007.02.018

Koenigstein S, Mark FC, Gößling-Reisemann S, Reuter H, Pörtner H-O (2016) Modelling climate change impacts on marine fish populations: process-based integration of ocean warming, acidification and other environmental drivers. Fish Fish 17:972-1004. https:// doi.org/10.1111/faf.12155

Lannig G, Flores JF, Sokolova IM (2006) Temperature-dependent stress response in oysters, Crassostrea virginica: pollution reduces temperature tolerance in oysters. Aquat Toxicol 79:278-287. https ://doi.org/10.1016/j.aquatox.2006.06.017

Lannig G, Cherkasov AS, Pörtner H-O, Bock C, Sokolova IM (2008) Cadmium-dependent oxygen limitation affects temperature tolerance in eastern oysters (Crassostrea virginica Gmelin). Am J Physiol Regul Integr Comp Physiol 294:R1338-R1346. https:// doi.org/10.1152/ajpregu.00793.2007

Lewis E, Wallace DWR (1998) Program developed for $\mathrm{CO}_{2}$ system calculations. United States: N.p. Technical Report ORNL/CDIAC105, Osti.Gov. https://doi.org/10.2172/639712

Livingstone DR (1991) Origins and Evolution of pathways an anaerobic metabolism in the animal kingdom. Am Zool 31:522-534. https://doi.org/10.1093/icb/31.3.522

Marshall DJ, McQuaid CD (1992) Relationship between heart rate and oxygen consumption in the intertidal limets Patella granularis and 
Siphonaria oculus. Comp Biochem Physiol A 102:297-300. https ://doi.org/10.1016/0300-9629(92)90583-C

Melzner F, Bock C, Pörtner H-O (2007) Allometry of thermal limitation in the cephalopod Sepia officinalis. Comp Biochem Physiol A 146:149-154. https://doi.org/10.1016/j.cbpa.2006.07.023

Millero FJ, DiTrolio BR (2010) Use of thermodynamics in examining the effects of ocean acidification. Elements 6:299-303. https://doi. org/10.2113/gselements.6.5.299

Møhlenberg F, Riisgård HU (1978) Efficiency of particle retention in 13 species of suspension feeding bivalves. Ophelia 17:239-246. https://doi.org/10.1080/00785326.1978.10425487

Müller M, Mentel M, van Hellemond JJ, Henze K, Woehle C, Gould SB, Yu R-Y, van der Giezen M, Tielens AGM, Martin W (2012) Biochemistry and evolution of anaerobic energy metabolism in Eukaryotes. Microbiol Mol Biol Rev 76:444-495. https://doi. org/10.1128/MMBR.05024-11

Newell RC, Johson LG, Kofoed LH (1977) Adjustment of the components of energy balance in response to temperature change in Ostrea edulis. Oecol 30:97-110. https://doi.org/10.1007/BF003 45414

Nicholson S (2002) Ecophysiological aspects of cardiac activity in the subtropical mussel Perna viridis (L.) (Bivalvia: Mytilidae). J Exp Mar Biol Ecol 267:207-222. https://doi.org/10.1016/S0022 -0981(01)00362-8

Nickerson DM, Facey DE, Grossman GD (1989) Estimating physiological thresholds with continuous two-phase regression. Physiol Zool 62:866-887

Nielsen M, Hansen BW, Vismann B (2017) Feeding traits of the European flat oyster, Ostrea edulis, and the invasive Pacific oyster, Crassostrea gigas. Mar Biol 164:6. https://doi.org/10.1007/ s00227-016-3041-5

Ortmann C, Grieshaber MK (2003) Energy metabolism and valve closure behaviour in the Asian Clam Corbidula fluminea. J Exp Biol 206:4167-4178. https://doi.org/10.1242/jeb.00656

Pazos AJ, Román G, Acosta CP, Abad M, Sánchez JL (1997) Seasonal changes in condition and biochemical composition of the scallop Pecten maximus L. from suspended culture in the Ria de Arousa (Galicia, N.W. Spain) in relation to environmental conditions. J Exp Mar Biol Ecol 211:169-193. https://doi. org/10.1016/S0022-0981(96)02724-4

Penn JL, Deutsch C, Payne JL, Sperling EA (2018) Temperaturedependent hypoxia explains biogeography and severity of endPermian marine mass extinction. Science 362:eaat1327. https ://doi.org/10.1126/science.aat1327

Petersen JK, Sejr MK, Larsen JEN (2003) Clearance rates in the Arctic bivalve Hiatella arctica and Mya sp. Polar Biol 26:334-341. https://doi.org/10.1007/s00300-003-0483-2

Poloczanska E, Brown C, Sydeman W, Kiessling W, Schoeman D, Moore P, Brander K, Bruno JF, Buckley LB, Burrows MT, Duarte C, Halpern BS, Holding J, Kappel CV, O'Connor MI, Pandolfi JM, Parmesan C, Schwing F, Thompson SA, Richardson AJ (2013) Global imprint of climate change on marine life. Nat Clim Change 3:919-925. https://doi.org/10.1038/nclim ate 1958

Pörtner H-O (2001) Climate change and temperature-dependent biogeography: oxygen limitation of thermal tolerance in animals. Naturwissenschaften 88:137-146. https://doi.org/10.1007/s0011 40100216

Pörtner H-O (2010) Oxygen-and capacity-limitation of thermal tolerance: a matrix for integrating climate-related stressor effects in marine ecosystems. J Exp Biol 213:881-893. https://doi. org/10.1242/jeb.037523

Pörtner H-O (2014) How and how not to investigate the oxygen and capacity limitation of thermal tolerance (OCLTT) and aerobic scope-remarks on the article by Gräns et al. J Exp Biol 217:4432-4433
Pörtner H-O, Knust R (2007) Climate change affects marine fishes through the oxygen limitation of thermal tolerance. Science 315:95-97. https://doi.org/10.1126/science.1135471

Pörtner H-O, Langenbuch M, Michaelidis B (2005) Synergistic effects of temperature extremes, hypoxia, and increases in $\mathrm{CO}_{2}$ on marine animals: From earth history to global change. J Geophys Res C 110:C09S10. https://doi.org/10.1029/2004JC002561

Pörtner H-O, Farrell AP, Knust R, Lannig G, Mark FC, Storch D (2009) Adapting to climate change-response. Science 323:876-877

Pörtner H-O, Bock C, Mark FC (2017) Oxygen-and capacity-limited thermal tolerance: bridging ecology and physiology. J Exp Biol 220:2685-2696. https://doi.org/10.1242/jeb.134585

Purohit PV, Rocke DM, Viant MR, Woodruff DL (2004) Discrimination models using variance-stabilizing transformation of metabolomic NMR data. OMICS 8:118-130. https://doi.org/10.1089/15362 31041388348

Rhein M, Rintoul SR, Aoki S et al (2013) Observations: ocean. In: Stocker TF, Qin D, Plattner G-K, Tignor M, Allen SK, Boschung J, Nauels A, Xia Y, Bex V, Midgley PM (eds) Climate change 2013: the physical science basis. Contribution of working Group I to the fifth assessment report of the intergovernmental panel on climate change. Cambridge University Press, Cambridge, pp 255-316

Riebesell U, Fabry VJ, Hansson L, Gattuso JP (2011) Guide to best practices for ocean acidification research and data reporting. European Commission EUR 24872, Publications Office of the European Union, Luxembourg. ISBN: 978-92-79-20650-4. https ://doi.org/10.2777/66906

Riisgård HU (2001) Comment: physiological regulation vs. autonomous filtration in filter-feeding bivalves: Starting points for progress. Ophelia 54:193-209. https://doi.org/10.1080/00785 236.2001.10409465

Riisgård HU, Larsen PS (2015) Research Note. Physiological regulated valve-closure makes mussels long-term starvation survivors: test of hypothesis. J Molluscan Stud 81:303-307

Riisgård HU, Kittner C, Seerup DF (2003) Regulation of opening state and filtration rate in filter-feeding bivalves (Cardium edule, Mytilus edulis, Mya arenaria) in response to low algal concentration. J Exp Mar Biol Ecol 284:105-127. https://doi.org/10.1016/S0022 -0981(02)00496-3

Sabine CL, Feely RA, Gruber N, Key RM, Lee K, Bullister JL, Wanninkhof R, Wong CS, Wallace DR, Tilbrook B, Millero FJ, Peng T-H, Kozyr A, Ono T, Rios AF (2004) The oceanic sink for anthropogenic $\mathrm{CO}_{2}$. Science 305:367-371. https://doi. org/10.1126/science.1097403

Schalkhausser B, Bock C, Stemmer K, Brey T, Pörtner H-O, Lannig G (2013) Impact of ocean acidification on escape performance of the king scallop, Pecten maximus, from Norway. Mar Biol 160:19952006. https://doi.org/10.1007/s00227-012-2057-8

Schiffer M, Harms L, Lucassen M, Mark FC, Pörtner H-O (2014) Temperature tolerance of different larval stages of the spider crab Hyas araneus exposed to elevated seawater $\mathrm{PCO}_{2}$. Front Zool 11:87. https://doi.org/10.1186/s12983-014-0087-4

Schmalenbach I, Buchholz F, Franke HD, Saborowski R (2009) Improvement of rearing conditions for juvenile lobsters (Homarus gammarus) by co-culturing with juvenile isopods (Idotea emarginata). Aquaculture 289:297-303. https://doi.org/10.1016/j.aquac ulture.2009.01.017

Schmidt M, Windisch HS, Ludwichowski KU, Seegert SLL, Pörtner H-O, Storch D, Bock C (2017) Differences in neurochemical profiles of two gadid specied under ocean warming and acidification. Front Zool 14:49. https://doi.org/10.1186/s12983-017-0238-5

Shepard S, Beukers-Stewart B, Hiddink JG, Brand AR, Kaiser MJ (2010) Strengthening recruitment of exploited scallops Pecten maximus with ocean warming. Mar Biol 157:91-97. https://doi. org/10.1007/s00227-009-1298-7 
Shumway SE, Koehn RK (1982) Oxygen consumption in the american oyster Crassostrea virginica. Mar Ecol Prog Ser 9:59-68. https:// doi.org/10.3354/meps009059

Sokolova IM, Frederich M, Bagwe R, Lannig G, Sukhotin AA (2012) Energy homeostasis as an integrative tool for assessing limits of environmental stress tolerance in aquatic invertebrates. Mar Environ Res 79:1-15. https://doi.org/10.1016/j.marenvres.2012.04.003

Somero GN (2002) Thermal physiology and vertical zonation of intertidal animals: optima, limits and costs of living. Integr Comp Biol 42:780-789. https://doi.org/10.1093/icb/42.4.780

Specht JA, Fuchs HL (2018) Thermal and viscous effect of temperature on mercenaria mercenaria suspension feeding. Mar Ecol Prog Ser 589:129-140. https://doi.org/10.3354/meps12431

Stanley SM (2016) Estimates of the magnitudes of major marine mass extinctions in earth history. PNAS 113:E6325-E6334. https://doi. org/10.1073/pnas.1613094113

Stoll MHC, Bakker K, Nobbe GH, Haesel RR (2001) Continuous-Flow analysis of dissolved inorganic carbon content in seawater. Anal Chem 73:4111-4116. https://doi.org/10.1021/ac010303r

Taylor AC (1976) The cardiac responses to shell opening and closure in the bivalve Arctica islandica (L.). J Exp Biol 64:751-759

Tripp-Valdez MA, Bock C, Lucassen M, Lluch-Cota SE, Sicard MT, Lannig G, Pörtner H-O (2017) Metabolic response and thermal tolerance of green abalone juveniles (Haliotis fulgens: Gastropoda) under acute hypoxia and hypercapnia. J Exp Mar Biol Ecol 497:11-18. https://doi.org/10.1016/j.jembe.2017.09.002

Trueman ER, Lowe GA (1971) The effect of temperature and littoral exposure on the heart rate of a bivalve mollusc, Isognomum alatus, in tropical condtions. Comp Biochem Physiol A 38:555-564. https://doi.org/10.1016/0300-9629(71)90122-8

Uppström LR (1974) Boron/chlorinity ratio of deep-sea water from the Pacific Ocean. Deep-Sea Res Oceanogr Abstr 21:161-162. https ://doi.org/10.1016/0011-7471(74)90074-6

Waters JF, Millero FJ (2013) The free proton concentration scale for seawater pH. Mar Chem 149:8-22. https://doi.org/10.1016/j. marchem.2012.11.003

Widdows J (1973) Effect of temperature and food on the heart beat, ventilation rate and oxygen uptake of Mytilus edulis. Mar Biol 20:269-276. https://doi.org/10.1007/BF00354270
Widdows J (1976) Physiological adaption of Mytilus edulis to cyclic temperatures. J Comp Physiol B 105:115-128. https://doi. org/10.1007/BF00691115

Wignall PB, Twitchett RJ (1996) Oceanic anoxia and the end Permian mass extinction. Science 272:1155-1158. https://doi.org/10.1126/ science. 272.5265 .1155

Wilson JG (1981) Temperature tolerance of circatidal bivalves in relation to their distribution. J Therm Biol 6:279-286. https://doi. org/10.1016/0306-4565(81)90016-4

Wilson JG, Elkaim B (1991) Tolerances to high temperature of infaunal bivalves and the effect of geographical distribution, position on the shore and season. J Mar Biol Assoc UK 71:169-177. https:// doi.org/10.1017/S0025315400037486

Xia J, Wishart DS (2016) Using metabo analyst 3.0 for comprehensive metabolomics data analysis. Curr Protoc Bioinform 55:14.10.114.10.91. https://doi.org/10.1002/cpbi.11

Xing Q, Li Y, Guo H, Yu Q, Huang X, Wang S, Hu X, Zhang L, Bao Z (2016) Cardiac performance: a thermal tolerance indicator in scallops. Mar Biol 163:244. https://doi.org/10.1007/s0022 7-016-3021-9

Yeager DP, Ultsch GR (1989) Phyiological regulation and conformation: a basic program for the determination of critical points. Physiol Zool 62:888-907

Zannella C, Mosca F, Mariani F, Franci G, Folliero V, Galdiero M, Tiscar PG, Galdiero M (2017) Microbial diseases of bivalve mollusks: infections, immunology and antimicrobial defense. Mar Drugs 15:E182. https://doi.org/10.3390/md15060182

Zittier ZM, Bock C, Lannig G, Pörtner H-O (2015) Impact of ocean acidification on thermal tolerance and acid-base regulation of Mytilus edulis (L.) from the North Sea. J Exp Mar Biol Ecol 473:16-25. https://doi.org/10.1016/j.jembe.2015.08.001

Publisher's Note Springer Nature remains neutral with regard to jurisdictional claims in published maps and institutional affiliations. 